\title{
Rethinking the Rat Trilogy: Detachment, Commitment and Haruki Murakami's Politics of Subjectivity
}
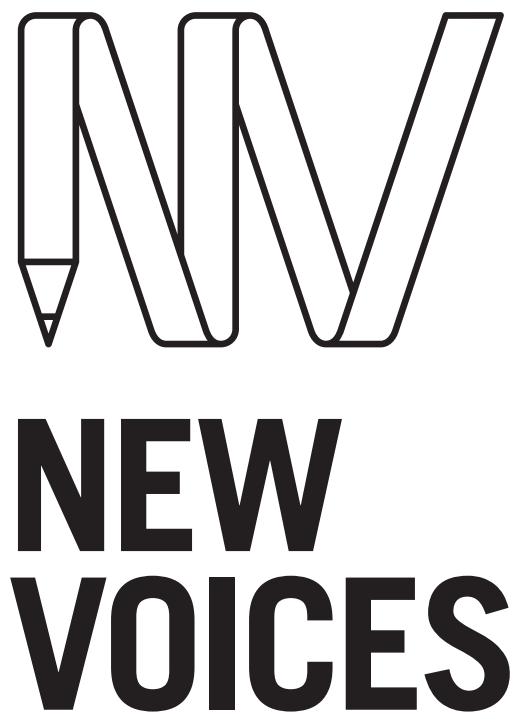

IN JAPANESE STUDIES

\section{A. K. BYRON \\ University of Sydney}

\section{ABSTRACT}

The career of novelist Haruki Murakami has conventionally been divided into two periods: detachment and commitment. Murakami's transition to commitment, in the sense of a social engagement with a defined political sensibility, is generally seen to begin with the novel The Wind-Up Bird Chronicle [1995]. However, the so-called Rat Trilogy (Hear the Wind Sing [1979], Pinball, 1973 [1980] and A Wild Sheep Chase [1982]) sees Murakami address the concept of shutaisei-the question of individual agency and subjectivity at the centre of Japan's student activist movement in the late 1960s. Examining the trilogy's central characters through the lens of shutaisei, I argue that a commitment to political and historical awareness can already be found in Murakami's early works.

\section{KEYWORDS}

1960s; everydayness; individuality; Murakami Haruki; New Left; politics; popular literature; postwar; student movement; subjectivity

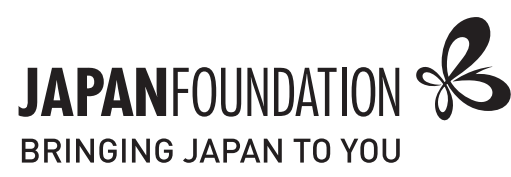

To link to this article: http://doi.org/10.21159/nvjs.09.03

\section{ISSN 2205-3166}

New Voices in Japanese Studies is an interdisciplinary, peer-reviewed journal showcasing the work of emerging scholars from Australia and New Zealand with research interests in Japan.

All articles can be downloaded free at newvoices.org.au

(C) The Japan Foundation, Sydney and A. K. Byron, 2017

\section{(c) (i) $(9)$}

This work is licensed under a Creative Commons Attribution-NonCommercialNoDerivatives 4.0 International License. 


\section{INTRODUCTION}

More than 30 years after his arrival on the Japanese literary scene, novelist Haruki Murakami [村上 春樹; b. 1949] now ranks as one of the true juggernauts of world fiction. A veritable publishing phenomenon in his homeland, Murakami's works of fiction and non-fiction have been translated into over 50 languages, often to substantial critical acclaim. However, for all their popularity among a general readership, many in Japanese literary circles have found Murakami's tales of calm, cool and collected magical realism to lack substance. Theorist Masao Miyoshi (1994) has described Murakami's novels as "smooth, popular [items] of consumption", about which "very few would be silly enough to get interested in deep reading" (244). ${ }^{1}$ Novelist Kenzaburō Ōe seemed to have had Murakami in mind during his 1994 Nobel Lecture, drawing a clear distinction between his own work and that of certain "other writers" whose novels were "mere reflections of the vast consumer cultures of Tokyo and the subcultures of the world at large".

Much of the debate regarding Murakami's value (or lack thereof) as a writer stems from his trademark air of “detachment” (デタッチメント)—a stylistic and narrative trait seen to typify much of his work (Watatsuki 2016, 6). His protagonists sit at a clinical, intellectual distance from the often fantastic and disturbing situations in which they find themselves, expressing minimal emotion. This is reflected on a structural level by Murakami's minimalistic, matter-of-fact prose, which draws heavily on English diction (Rubin 2002, 36). Crucially, this perceived detachment is often taken to reflect a general apathy in Murakami's writing toward social realities and moments of historical significance in Japanese society, such as the Kobe earthquake of 1995 and the Tōhoku earthquake and tsunami of 2011 (Kuroko 2015, 219-20).

Murakami has suggested this sense of detachment emerged after the Japanese student movement of the late 1960s, remarking in a conversation with psychoanalyst Hayao Kawai:

When I think about it, during the university struggles of 1968-1969, I was very concerned about what I should personally make a commitment to. [...] That time was the age of commitment for our generation. But then that got beaten down, and beaten out of us, and all in an instant it turned into detachment. ${ }^{3}$

(Kawai and Murakami 1996, 12-13)

For critics such as Kōjin Karatani (1990), this detachment is symptomatic of a lack of political awareness and a sense of historicity (102). The idea that serious literature in Japanese must, by definition, reflect on Japanese social reality is one with a long precedent in domestic critical discourse. As the critic Ken Hirano observes, the privileged category of junbungaku (純文学; lit., 'pure literature' or high literature) requires by definition a sense of “actuality” (アクチュアリティ), in terms of engaging with and commenting 
on social realities (Kimura 2014, 7). In such an understanding, fictions of detachment are not considered to fall under the category of junbungaku, and are therefore rarely given serious critical attention. This generic hierarchy is reflected in the usual categorisation of Murakami's novels as taish $\bar{u}$ bungaku (大衆文学; popular literature).

This is not to suggest that Murakami has been entirely ostracised by Japan's literary establishment: after all, he was awarded the Tanizaki Jun'ichiro Prize for his 1985 novel, Hard-Boiled Wonderland and the End of the World. Moreover, more recently, some critics in Japan have observed a "transition" (転換) at play in Murakami’s attitudes towards social and political engagement (Kuroko 2007, 10-11). ${ }^{4}$ For his part, Murakami refers to this transition as moving from a position of “detachment to commitment” (デタッチメント からコミットメントへ) (Kawai and Murakami 1996, 12-13). The notion of a transition towards social 'commitment' has since come to inform a substantial amount of scholarship on Murakami's work (Kuronuma 1999, 64). For critics such Kuroko and Ōe, this 'commitment' seems to form the most important criterion that distinguishes Murakami's works of mass-market fiction from those approaching a junbungaku designation.

Murakami's transition from detachment to commitment is generally thought to begin in earnest with a detailed thematic exploration of Japanese wartime atrocities in China, in the novel The Wind-Up Bird Chronicle [1995] (Tanaka Atkins 2012, 7). Murakami himself observed this change, remarking to Kawai:

More recently, I've been thinking a lot about the concept of commitment. For example, even when I'm writing a novel it's become a very important thing for me. Though up until now detachment has been important for me. ${ }^{5}$

(Kawai and Murakami 1996, 12-13)

Murakami returned to this point later in their discussion:

There were three steps in The Wind-Up Bird Chronicle for me. First came the aphorism and the sense of detachment, and then the process of telling the story itself, but ultimately I came to feel that something was missing. I suppose this is how commitment came into it, though I'm still sorting that out for myself. ${ }^{6}$

(Kawai and Murakami 1996, 70)

This shift towards incorporating commitment, however unsteady, somewhat softened the attitudes of some of Murakami's most vocal detractors. Though he would later renege on the assessment, critic Haruo Yoshida (1997) hinged an entire book on the central argument that Murakami was undergoing a critical transition towards a sense of historical engagement in the mid-1990s. Yoshida considered the non-fiction essay collection Underground [1997]—an 
investigation of the March 1995 Tokyo subway sarin attacks by the doomsday cult Aum Shinrikyō $\overline{0}^{7}$ to be a watershed moment for the writer. However, judging from the works upon which critics have focused their harsher remarks, Murakami's tendency toward detachment is best exemplified by his earliest novels, in particular the so-called Rat Trilogy.

The Rat Trilogy consists of three stand-alone novels that are interconnected by their central characters: Hear the Wind Sing [1979]; Pinball, 1973 [1980]; and A Wild Sheep Chase [1982]. ${ }^{8}$ For his part, Murakami has considered at least the first two books to be among his weaker works, even going so far as to have vetoed their official release in the English-speaking world for over 20 years (Murakami and Wray 2004). ${ }^{9}$ But despite their relative immaturity, these early works are significant because they represent fundamental characteristics of his writing style. Many classic Murakami tropes make their first appearance in the Rat Trilogy: the meditations on American pop music; continental philosophy and whiskey; the intrusion of the uncanny into the mundane; and the appearance of a mysterious woman with beautiful ears, with whom the unnamed narrator eventually has sex. Significantly, these books establish a model of exploring the individual as a form of "self-therapy", which recurs in Murakami's later works (Dil 2010).

However, the Rat Trilogy also poses a problem for the conventional understanding of Murakami's supposed trajectory from detachment to commitment. Although usually read as meditations on individual psychology and loss, the long shadow of Japan's tumultuous era of student protests in the late 1960s informs Murakami's construction of the individual in all three of these works. By design or otherwise, Murakami's focus on interiority dovetails elegantly with the discourse of shutaisei (主体性; roughly understood as 'individual subjectivity') that sat at the heart of the student protest movement (Kersten 2009, 229).

Despite its importance in postwar discourse, there is no single authoritative definition of what shutaisei is or how one goes about attaining or achieving it. However, common to the multivalent usages of the term, shutaisei in postwar Japanese thought was a concern with the capacity of the individual to perceive, react to and enact change upon one's environment, according to an independent definition of moral values (Koschmann 1996, 3-4). To defend shutaisei was to defend the value of thinking for oneself in the face of authoritarianism, and of the individual subject's free will (Sasaki 2012, 63).

While shutaisei was a fixture in discussions among progressive intellectuals of all stripes in the postwar era, the New Left discourse in Japan hinged on theorising the tension between individual shutaisei and the need to participate in actions to transform the wider society (Eckersall 2013, 89).

\footnotetext{
7 On 20 March 1995, members of the Aum Shinrikyō cult simultaneously released sarin nerve gas on five Tokyo subway trains in a coordinated attack during the morning rush hour. The attack eventually killed 13 people, severely injuring dozens, and potentially affected up to 6,000 commuters.

8 Dance Dance Dance [1988] follows the events of A Wild Sheep Chase but is generally excluded from the Rat Trilogy as the titular character is dead by this point. 
In the Rat Trilogy, Murakami explores this same politically charged dimension of subjectivity through the central characters' development. Though Murakami does not conceive of it in these terms, the arc towards commitment can be seen to form a crucial subtext of these early works.

\section{DETACHMENT AND THE CRITICAL RESPONSES TO MURAKAMI'S RAT TRILOGY}

The Rat Trilogy derives its title from the character Nezumi (鼠; Rat). Rat's counterpart is the series' co-protagonist, an unnamed narrator who refers to himself by the informal, first-person masculine pronoun boku (僕). Boku begins the series in Hear the Wind Sing as an amiable if withdrawn student in his final year of university, returning home to the rural coast for summer vacation with his slightly older friend, Rat. Boku is somewhat alienated from the mainstream, and from time to time offers withering critiques of social conformity in the broadest sense. However, for the most part, he appears to enjoy a simple lifestyle of consumer comforts; brand name liquors, FM radio, jazz, sex and food all make frequent appearances in his narration. Although Boku had a tangential engagement with the student movement-attending a few demonstrations, sleeping with a runaway girl on the fringes of the movement and generally sympathising with its goalsRat was more involved and faced serious repercussions, including police violence. Rat is brash and emotional, and despite being in his early twenties has made no attempt to embark on any particular career path. By the novel's ambiguous conclusion, the different trajectories of the two friends' lives appear to have diverged beyond recourse.

Murakami introduces surreal elements in the novel's sequel, Pinball, 1973. Having moved to Tokyo to work as a translator, Boku finds himself driven to seek out a particular pinball machine he had briefly enjoyed playing in his hometown in the late 1960s. The anthropomorphic presence of the threeflipper Spaceship pinball machine, combined with the sudden appearance of identical twin girls in Boku's apartment, heralds the arrival of the matter-offact magical realism that has become Murakami's trademark. Rat, meanwhile, remains in the seaside town, only to break up with his girlfriend and eventually move to the mountains. Despite mutual expressions of nostalgia and loneliness, neither character attempts to interact with the other at any point during the year the novel describes.

A Wild Sheep Chase opens some years later, in 1978, with the protagonist Boku living in Tokyo. One day he is summoned by a third character, referred to as the "Strange Man", who is the deputy of a “far-right kingmaker" (右翼 の大物) in search of a mysterious 'sheep' on pain of personal and professional ruin (Murakami 1990b, 80). The sheep, appearing in a photo sent to the protagonist by Rat, brings the two characters' lives into alignment for the last time. As the mystery of the sheep brings Boku to Hokkaido, Rat ultimately commits suicide to seal the sheep in his body and save Japan from the sheep's further malevolent influence. 
According to Seiji Takeda, critics viewed the Rat Trilogy as a failure due to its lack of “sociality” (社会性), referring to the works' inability to describe social realities, and its lack of “historicity" (歴史性), in terms of the narrative's position in the broader scope of Japanese history (Seats 2006, 116). The dominant critical discourse at the time of the series' publication commonly referred to Murakami's prose as typifying a kind of "autism" or "self-closure" (自閉), and a desire for an “escape from the Other” (他者からの逃避) (Takeda 1995, 32). Takeda defends Murakami on this charge, suggesting that the novels' sense of social detachment is a deliberate aesthetic strategy that allows Murakami to explore the universal and timeless concerns of emotion, imagination and the human condition-a strategy that has contributed to his international success (Takeda 1995, 34-35).

However, I contend that the notion of the Rat Trilogy as typifying the detached period of Murakami's writing stems largely from the characterisation of Boku, who, as the narrator, has been the primary focus of critical attention to date. On the other hand, despite the use of his name in the informal title of the series, the character of Rat-described rather uncharitably by critic Steve Erickson (2015) as "a loudmouth barfly and determined human disaster"-has attracted relatively little critical attention. While much of these books' charm and innovation comes from their unnamed narrator's prose, by focusing instead on the dichotomy of Boku and Rat, the series can be seen as a political allegory for the collapse of the 1960s student protest movement and its cultural aftermath. These characters' interactions across the three novels demonstrate that a clear arc towards commitment is present even in Murakami's earliest writings, which engage directly with the student movement's political discourse of individual selfhood and social resistance.

\section{DEBATING SUBJECTIVITY IN THE 1960S STUDENT MOVEMENT AND ITS AFTERMATH}

The Rat Trilogy unfolds in the context of the aftermath of the late 1960s student protest movement, the discourse around which appears to have deeply informed Murakami's sense of political engagement. While a historiographical assessment of the student protest movement in postwar Japan is beyond the scope of this article, a brief overview is important to contextualise Murakami's construction of the individual in these early novels.

The student movement that rocked university campuses across Japan in the late 1960s had its origins in earlier civil demonstrations-namely, those against the 1960 extension of the Treaty of Mutual Cooperation and Security between the United States and Japan (日本国とアメリカ合衆国との間の相互協 力及び安全保障条約), known by the abbreviation Anpo (安保). This vigorous protest movement stemmed from popular opposition to the conservative Kishi government's plans to renew the Anpo treat ${ }^{10}$-a move broadly 
opposed as both a step towards remilitarisation and a gesture of continued subservience to the United States. Accompanied by a series of yearly general strikes, the anti-Anpo movement was widely feared by conservatives to have brought Japan to the "brink of revolution" (Takayama 2007, 97).

The anti-Anpo movement of 1960 encompassed a broad swathe of Japan's civil society, ranging from established socialist factions like the Bund (League of Revolutionary Communists) and the Japanese Communist Party (JCP), to labour unions, citizen groups, families with young children, women and neighbourhood organisations. Student organisations, particularly the leftleaning Zengakuren (全学連; All-Japan Student Union), played an important role in the struggle. But when the Anpo treaty was renewed despite the massive civil outcry, many younger activists became dejected, breaking off from the Bund and the JCP. Japan's New Left and its more ideologically ecumenical cohorts emerged within this younger generation of 1960s activists, with their activities centred on the campuses of major universities, and eventually spreading to high schools (Kelman 2001, 246).

The majority of young people who came of age in the late 1960s did not directly take part in the movement. With matriculation levels on the rise throughout the decade, many students remained perfectly motivated to continue studying and working (Oguma 2015). Even the most charitable estimates suggest that a maximum of just $20 \%$ of students across the country were even passively involved in the demonstrations at their peak (Oguma 2015). Nevertheless, as Guy Yasko (1997) observes, the ubiquity of its highly visible tactic of mass demonstration, in the mass media, meant the student movement quickly became part of Japan's collective experience of the late 1960s (5).

\section{DEBATING SUBJECTIVITY AND EVERYDAYNESS}

The summer of 1970, which forms the backdrop of Hear the Wind Sing, was a period of significant historical change. Though protest activities did continue after this point, 1970 has served as a benchmark in that it heralded the unofficial 'defeat' of the 1960s protest movement on several (if not all) fronts, and most obviously with the second renewal of the Anpo treaty in June of that year. From 1969 onwards, police expanded their use of mass arrest at student demonstrations, a tactic held as justified under the 1952 Antisubversive Activities Law (破壊活動防止法). The increasing threat of mass arrest effectively stifled large-scale protest tactics such as university barricades-a tactic to which Murakami alludes in the trilogy (Ando 2013 , 81). These years also saw the widespread use of legislation allowing prospective employers to effectively blacklist students found to have taken part in demonstrations (Steinhoff 1984). In short, the beginning of the 1970s marked a turning point when many student activists became disenchanted and left the movement, and the incarnation of the student protest movement in which the characters of Hear the Wind Sing participated faced a rapid decline. 
Hear the Wind Sing resonated as a coming-of-age novel for a decidedly different generation when it was first published in the popular literary magazine Gunzō [群像] in 1979. Right-wing critic Keigo Okonogi (1978) borrowed from Erikson's theory of psychosocial development in describing the youth of this period as moratoriamu ningen (モラトリアム 人間; lit., 'moratorium people')—the generation which agreed to a moratorium on demands and protests for political and social autonomy, in exchange for consumer luxuries and greater security (17). Under Okonogi's quasi-psychoanalytic discourse, the political and social engagement of late 1960s youth who had been involved with the protest movement became synonymous with unwarranted emotional reactivity, while the generation that had come of age during the 1970s was seen as dispassionate and detached (Kinsella 1998, 292). With Murakami's works often cited as exemplifying this new brand of cool, apolitical detachment in the wake of the student movement's dissolution, his phenomenal rise in popularity over the course of the 1980s has been attributed at least in part to this pattern of generational and political shift (Beale 1991).

In the Rat Trilogy, Murakami depicts two characters, Boku and Rat, who are left to make sense of their lives after the student movement as they knew it was crushed. Where Boku abandons all but his nostalgia for 1960s pop culture and moves into a comfortable (if unsatisfying) life as a middle-class Tokyoite, Rat stays true to his protest-era values of non-conformity and resistance to authority, even when it becomes evident that the movement has lost supportby which point Boku comes to see him as an embittered neighbourhood barfly, stuck in the past while the world has moved on. Through these two starkly different men, Murakami explores what Rikki Kersten (2009) identifies as the movement's overarching concern: disagreements over the nature of social and political subjectivity, or shutaisei (6).

The question of individual moral agency in the form of shutaisei became the nexus of postwar liberal thought in Japan. For the postwar progressive school of thought, the project of postwar democratisation could only be accomplished through the full realisation of individual shutaisei in public life. These views were most commonly associated with Tokyo University law scholar and public intellectual Masao Maruyama [1914-1996]. Despite the ultimate passage of the controversial security treaty, Maruyama lauded the dynamism of the 1960 Anpo protests as "the indigenisation of democracy" (Kersten 2009, 232) insofar as they spurred the Japanese citizenry towards a sense of shutaisei mediated by democratic institutions in the public sphere (i.e., the free press, universities and citizen groups). But by the end of the 1960s, with much of the liberal establishment seen as failing to address their concerns, such an understanding of shutaisei was unconscionable to many in the student movement.

The student movement soon found one of their champions in the theorist and New Left leader Takaaki Yoshimoto [1924-2012]. In Yoshimoto's assessment, the supposed institutions of postwar democracy had failed to foster genuine shutaisei and left no capacity for moral self-expression; the students protesting 
in the late 1960s had not done so out of a civic duty to check the power of the State, as Maruyama had suggested, but out of total frustration with the depressing realities of the postwar establishment (Kersten 2009, 233). For the New Left school of thought and the student protest groups aligned with it, shutaisei was not meted out to citizens by the organs of the public sphere, but was rather the outcome of an individual process of what activists such as Makoto Seimiya termed “self-transformation” (自己変革) (Ando 2013, 69). My argument focuses on a similar understanding of shutaisei as the capacity of the individual moral subject to perceive social and political realities, and become empowered to enact change upon them.

Although driven by political goals, the student movement engaged with the discussion of shutaisei in explicitly individualistic terms, emphasising the importance of one's moral interiority. Eiji Oguma (2009) quotes one activist as observing that "the nuance [of the term shutaisei] was about harsh self-excoriation, speaking for yourself in your own words, and thinking for yourself” (自分自身の自己切開、自分の言葉で語れ、自分で考えろ というニュアンス) (579). To them, the term also carried a nuance of “enthusiasm" or "motivation" (やる気) and of "not sitting on the fence" (日和らない) (577). According to Takemasa Ando (2013), the student activists did not seek immediate legislative or political reform, but believed that social change would follow from their collective experience of selfreflection and transformation (73).

However, the significance of the abstract concept of 'individual subjectivity' in the context of the student movement should not be overstated. For all its splintering and discontent, it was a serious political movement that sought to achieve a number of tangible reforms. But by the same token, affirmation of the need for individual subjectivity and moral self-examination of one's position in society formed a key part of the movement's rhetoric and praxis. Ando (2013) contends the focus of the student movement was to "transform [the people's] depoliticized consciousness" (1). Critically for our discussion of Murakami, Ando refers to this as a conscious rejection of "everydayness", or nichijōsei (日常性) (1). For the students, nichijōsei referred to the entire complex of both social pressures towards conformity and the tangible agents of force that gave these pressures weight (such as the police and the higher education system). As one Nihon University student described it in a roundtable at that time, this everydayness referred to

"the dominant way of thinking-everything ranging from people's art of living better to the cognitive system academically discussed by intellectuals": the politics of "representative democracy", the economics of "rapid growth", and people's expectations that "someday their hopes will be realised". Being suspicious of these things and unveiling them is "getting out of everyday-ness". (Ando 2013, 73)

Reflecting on everydayness in this sense entailed the profession-bound university students questioning their own affluence amid the burgeoning economic boom, and choosing to live differently. Shutaisei was an essential 
precondition to challenging everydayness through the movements' tactics including demonstrations and sit-ins. In addition to whatever concrete political goals a particular direct action may have been aiming for, an equally important goal of the Japanese student movement as a whole was to make visible the invisible networks of social control and conformity that had been internalised as 'just the way things are', and which impeded the development of authentic shutaisei. For many activists in the New Left, challenging such everydayness also included a tendency to reflect on wartime atrocities at home and abroad, and acknowledge the role of postwar Japanese citizens as victimisers, or at the very least complicit beneficiaries of the victimisation of others throughout Asia (Ando 2013, 175). Moral subjectivity at the level of the individual became intrinsic to the students' logic of enacting social justice on a broader scale.

\section{ALLEGORIES OF SUBJECTIVITY IN HEAR THE WIND SING}

If shutaisei is to be understood as the capacity for the democratic subject to both perceive and enact change upon society in accordance with one's own values, then Boku fulfils this capacity. We see the world through his recollections and observations, and through his reflections of the characters that open up to him. At the same time, he is also extremely passive, both socially and politically. In the absence of an overriding moral code connecting him to other human beings, he appears to fixate on tangible elements of cultural detritus, a tendency suggested by his encyclopaedic knowledge of 1960s pop music and the fictional sci-fi author Derek Hartfield. Boku perceives the world around him quite astutely, but feels nothing in particular about it, and is therefore not motivated to change any part of it. Boku's passive consumerist philosophy is precisely what gives rise to the sense of detachment seen to typify Murakami’s early work more generally.

Rat, meanwhile, retains the strong sense of shutaisei he picked up as a student activist. He has developed certain independent moral values and reacts accordingly. He has his moments of self-awareness. For instance, although he decides to run away to the mountains and write novels, he does so under no illusions of aptitude: “I don't think I have talent or anything” (俺は叔、自分に 才能があるなんて思っちやいないよ) (Murakami 1990a, 121). ${ }^{11}$ But Boku looks down on Rat's novels as absurd stories detached from the human experience, remarking with a backhanded compliment:

Rat's stories always follow two rules: first, there are no sex scenes, and second, not one person dies. Even if you don't acknowledge it, people die and guys sleep with girls. That's just how it is. ${ }^{12}$

(Murakami 1987, 18)

Rat's lack of ability rules out artistic endeavours as an outlet for his sense of disillusionment once he can no longer participate in protest actions. In the absence of an organised student protest movement to give him some sense 
of purpose, he cannot live in the world as he wants to. However, he also lacks the perceptiveness to identify and enact any meaningful resistance against the systems of power and social relations that have removed student protest as a viable outlet for his dissatisfaction in the first place. Since he is not fully utilising his shutaisei through political engagement, he becomes a tragicomic figure waxing analytical about inequities in the class system while coasting by on his family's wealth.

We first meet Rat in the recurring setting of J's Bar, where he opens the novel by shouting out “Eat shit, you rich bastards!” (金持ちなんて・みんな・翼くらえ さ) to no-one in particular (Murakami 1990a, 12). On one level, Rat seems to form a caricature of the typical 'angry young man' associated with the late 1960s student protests. The scion of a wealthy family that made its riches in the war, Rat has bitterly renounced his own privilege, become absorbed in student activism, and ultimately dropped out of university under questionable circumstances about which he refuses to go into detail. ${ }^{13}$ When Boku points out that he is one of the elite about which he complains, Rat posits that the dividing line between himself and the rich is not a matter of economics but one of character, as he needs to "use his brain in order to live” (生きるためには考え続けなくちゃならない), as opposed to the rich, who “don't have to think about important things” (奴らは大事なことは何も考えない) (Murakami 1990a, 14-15). Rat seems to be a satirical representation of the intellectual Left who were, on the whole, from rather privileged backgrounds that allowed them access to higher education in the first place. But there is nevertheless something endearing about him, and for all his flaws Boku views him as a loyal friend.

The contrast between these characters extends into the syntactical structures Murakami uses to render them. Where Boku's dialogue is relatively polished and spare, Rat's speech is more impassioned and conversational, such as his use of ore (俺), a much more informal masculine first-person pronoun. Rat strikes a more colloquial tone; he enjoins Boku's participation with the liberal use of interjectory particles and phrases, such as 'I'll come right out and say it’ (はっきり言って), 'Hey’ (ってね), 'Right?’ (ってさ), 'Don’t you think...' (そう だろ) and 'You see?' (〜くない). The narration also lingers on Rat's impolite manners, describing moments of fidgeting with his hands, blowing his nose and drunkenly vomiting with a regularity that imbues him with a sense of restless energy and compulsion toward self-expression.

When Boku leaves town at the end of Hear the Wind Sing, the move appears to push Rat into depression, with the ever-perceptive bartender J observing that Rat's persistent unhappiness appears to come down to being “worried about being left behind” (多分取り残されるような気がするんだよ) (Murakami, 1990a, 85). Yet this fear is not enough to motivate Rat to follow Boku into the conventional labour market. Later, in a subsequent conversation with Boku, Rat takes on an ironic messianic tone, quoting the Bible verse Matthew 5:13: 
"Ye are the salt of the earth, but if the salt hath lost its savour, wherewith shall it be salted?” (汝らは地の塩なり。……塩もし効力失わば、何をもてか之に 塩すべき) (Murakami 1990a, 92). ${ }^{14}$

Murakami would be well aware of this verse's conclusion of tasteless salt: "[I]t is thenceforth good for nothing, but to be cast out, and to be trodden under foot of men" (Matthew 5:13 King James Version [KJV]). Refusing to let go of the sense of shutaisei he picked up as an activist, Rat is at risk of being left behind as the world changes around him, and that is exactly what happens. While the generally introverted Boku strives for a measure of upward mobility by settling down to start a business in Tokyo, Hear the Wind Sing ends with Rat remaining in the nameless seaside town and considering writing, as he muses: "The cicadas and frogs and spiders, the summer grass and the wind, if I could write for them, it would be a wonderful thing" (蝉や蛙や蜘蛛や、そして夏草や風のために何かが書けたらどんなに素敵だろう つてね) (Murakami 1990a, 92). ${ }^{15}$ However conflicted he may feel about it, in abandoning his friendship with Rat, Boku has not only stepped away from his own shutaisei, but made a choice to detach himself from the one meaningful social connection he retains from the activist circles. Therefore, rather than detachment being figured as a sensible lifestyle choice for a post-protest youth, Boku's rejection of Rat comes with a profound sense of loss and isolation.

\section{DETACHMENT AND CONSUMERISM IN PINBALL, 1973}

Pinball, 1973 returns to the two characters some three years later, by which stage they live roughly 650 kilometres apart: Boku working as a translator in Tokyo, and Rat still in the seaside town. It is in this novel that Murakami's signature uncanny tension between reality and unreality first begins to take shape. In the time elapsed since the events of Hear the Wind Sing, the two former friends have fallen out of touch, with their time occupied by what could be described as misdirected passions. Murakami sketches these as vignettes in a series of alternating chapters, moving between Boku and Rat's otherwise unconnected lives. The alternating chapters of the book sit at thematic opposites, helping to illustrate the gulf between the characters; Boku tells a detached, matter-of-fact account of a series of highly poignant and at times fantastic scenes, while Rat's side of the story is a tense and emotionally charged account of the several dull weeks before his decision to finally leave town.

Even as Boku appears to be reasonably content with his modestly successful professional life in Tokyo-reading Kant, listening to the Beatles and sleeping with identical twin girls-his thoughts keep bringing him back to the 1960s and his time with Rat. He begins to think back on a twisted version of the late 1960s, recalling his time at the university barricades as a peaceful wonderland where he bonded over classical music with "a man from Saturn, and another one from Venus, one each” (僕が話した相手の中には土星生まれと金星生まれが 一人ずついた) (Murakami 1990a, 136). ${ }^{16}$ Gripped by a sense of nostalgia, Boku 
begins to use his newfound affluence and leisure time to cultivate an otakulike interest in cultural ephemera of the late 1960s, reading widely and listening to pop records religiously. Out of nowhere, he develops a sudden obsession with a particular pinball machine he and Rat had played, the threeflipper Spaceship, and follows a complex series of clues to its final resting place. In a surreal scene that bookends Boku's earlier recollections of meeting friendly humanoid aliens at the university blockades, Boku and the talking pinball machine reminisce on the old days for one last time. In the absence of Rat's idealism or J's sage words of advice, Boku seems to have begun attributing subjectivity to inanimate objects, while his fetishistic consumerism appears to have reduced his ability to form human relationships.

Boku is lucid enough to recall that Rat was a fanatical devotee of the threeflipper Spaceship in 1970, thinking back on a heartwarming snapshot of Rat's high score, which "forged a bond between Rat and the machine, perhaps even a feeling of kinship”(鼠とピンボール台を結びつけ、そこはかとない親密 な雰囲気をかもしだしていた) (Murakami 1990a, 203). ${ }^{17}$ Boku’s thoughts turn briefly to Rat, who once dreamily promised he would never get sick of pinball. In this sense, Rat's unwavering determination to the quixotic goal of reaching the high score stands in for the sense of protest era shutaisei that Boku implicitly seeks. However, Boku's lack of emotional self-scrutiny leads him to project his nostalgia for that era onto the physical object itself rather than the social milieu in which he encountered it. The accomplishment of Boku's quest is therefore rendered absurd and disjointed: the novel's mysterious climax sees him organise a reunion with the now-sentient three-flipper Spaceship, but this final rendezvous takes place in a cold, filthy chicken coop, rank with death and manure (Murakami 1990a, 232-42).

By 1973, Boku has become so ensconced in the logic of consumerism that the idea of satisfying his nostalgia by reaching out to Rat-who seemed to embody the anti-establishment vigour of the student movement-does not occur to him. Boku's pop culture nostalgia, to become a hallmark of Murakami's style, is an ironically misplaced longing for his youth that can never be fulfilled as long as he refuses to engage with the sticky questions of class and privilege that go along with establishing one's shutaisei. As a stand-in for the apolitical 'moratoriamu ningen' set who have withdrawn from the self-transformation logic of protest, Boku has outsourced his sense of shutaisei to commodities. The grotesque absurdity of the lengths to which he goes to satisfy his banal desire for pinball suggests that we should not necessarily consider him a role model.

Meanwhile, now 25 years old, Rat has settled into an apartment paid for by his wealthy family and has taken an attractive older woman as his lover. For all intents and purposes his life appears relatively comfortable, yet the year of 1973 holds “something spiteful” (何かしら底意地の悪いもの) for Rat (Murakami 1990a, 149). ${ }^{18}$ Rat's anxieties seem to centre on his relationship with his nameless girlfriend; although she inspires in Rat a long-forgotten tenderness, she also represents a practiced inauthenticity that would have 
been anathema to the Rat of 1970. Rat notices in her mannerisms, from her choice of sundress to a smile that belies a certain studied sprezzatura and self-awareness, that she is striving to cultivate a "certain perfection, within her own little world, and with remarkable effort" (Murakami 1990a, 172). ${ }^{19}$ Despite Rat's affection for the woman, such a relationship poses a dilemma for the man who had staked his identity on a refusal to conform.

To return to the scriptural metaphor flagged by Rat in Hear the Wind Sing, Rat now appears to be at risk of losing his 'salt' after all. Surrounded by the relative comfort of a spacious apartment, he has begun to tamp down his former wildness, seen in Hear the Wind Sing. Although both Boku and Rat's narratives explicitly refer to scenes of university protest, Rat has begun to distance himself from the student movement, growing anxious at the prospect of explaining his involvement and speaking only vaguely of his reasons for leaving university, saying, "We just couldn't get along, the university and me” (お互い好きになれなかったんだ、俺の方も大学の方もね), when in fact he had dropped out under a cloud of suspicion due to his involvement with the protests (Murakami 1990a, 153). ${ }^{20}$ With his pleasant but vapid girlfriend, chain-smoking habit and newly adopted jukebox hobby at J's Bar, it seems that Rat is shadowing Boku's former lifestyle in the townagain, as seen in Hear the Wind Sing. Rat appears to be attempting to suppress the suspicion of everydayness that he had once cultivated as an activist, no longer launching into diatribes about rich people, and accepting a stipend from the family fortune Rat's father had accumulated during the war. Although he is unconscious of it, Rat's rejection of his previously treasured shutaisei drives him into a deep depression.

In Tokyo, Boku seems to be attempting to resolve lingering emotional issues regarding his university girlfriend Naoko's suicide and his estrangement from Rat. On the other hand, Rat's attempts to conform to societal expectations of adult behaviour are what appear to be dragging him back into a period of stasis. Rat himself seems to be aware of this, with the third-person narration returning on several occasions to his sense of time becoming unclear or slowed. Rat shares his anxiety with $\mathrm{J}$ the bartender, equating it with a visceral sense of decay:

"Say J, I've been thinking-people-I don't care who-all get to rotting. Am I right? [...] People go through changes, sure. But up to now, I never did get what those changes were supposed to mean. [...] Then it came to me. Whatever step forward, whatever the change, it's really only a stage of decay. ${ }^{21}$

(Murakami 1985, 142)

Further to this, Rat is only able to regain his sense of self-esteem in moments of destructive behaviour, with Murakami describing in uncomfortable detail one night when Rat drinks eight beers at J's Bar before vomiting in the women's restroom. After cleaning himself up a little, Rat takes a moment to look in the mirror and finds himself handsome once again. This takes us back 
to Boku's first encounter with Rat as a student activist, when he had also been drunk and inexplicably charismatic (Murakami 1990a, 15). Reconnecting with the same excess that marked his youth temporarily restores his sense of shutaisei. It is soon after that Rat finally makes the decision to abandon his unsatisfying relationship and leave the town forever. His year in Pinball, 1973 ends ambiguously on the precipice of this journey. Exhausted, despondent, and possibly considering suicide, he reflects: "It must be warmer than any town at the bottom of the sea. More quiet and peaceful, too, I bet. No... I don't wanna think about anything anymore” (そして海の底はどんな町よりも暖 かく、そして安らぎと静けさに満ちているだろうと思う。いや、もう何も考えたくない) (Murakami 1990a, 244).

Having found the trappings of Boku's more restrained consumerist lifestyle to be incompatible with his non-conformist sense of self, Rat retreats to the countryside to work on his novels. Art seems to call to him as an escape from the everydayness by which his life in Boku's shadow was plagued; but as the following novel reveals, it is not a permanent retreat.

\section{COMMITMENT, WITHDRAWAL AND CHALLENGING EVERYDAYNESS IN A WILD SHEEP CHASE}

The concluding book of the trilogy, A Wild Sheep Chase, differs substantially in tone and content from the previous two. Whereas Hear the Wind Sing is a largely realistic exploration of relationships, and Pinball, 1973 begins to flirt with the uncanny through the search for the three-flipper Spaceship, in the final book magical realism becomes central to the plot. This opens up a far wider symbolic vocabulary with which Murakami explores the increasingly strange world of Rat and Boku. This offers a complex and accomplished denouement to the conflicting paths of Rat and Boku, resolving Rat's acceptance of his choices, and granting some avenue for Boku to express his shutaisei by enacting resistance against the ominous forces lurking behind everydayness.

As is revealed gradually through the novel's nonlinear progression, the sheep appears to be a malevolent spiritual entity that possesses human hosts through a cyst in the brain. Through Boku's journey to track down the sheep in Hokkaido, Murakami traces the sheep's mysterious power through the embedded historical connections of its former hosts. Boku's encounters lead him to two such hosts: the Sheep Professor, an elderly eccentric who was possessed by the sheep while conducting research in occupied Korea; and the Boss, a convicted war criminal who under the sheep's influence has taken control of postwar Japan's major conservative political party, and also runs a large and powerful media outlet.

In this way, Murakami associates the sheep with Japan's colonial aggression and the far-right influence on the country's political and business structure, suggesting an inevitable progression towards violent expressions of power. The mind-controlling ability of the sheep itself is similarly associated with 
invasive violence, and its former hosts describe the process in terms such as “the sheep is inside me” (羊が私の中にいる) - a turn of phrase that the Sheep Professor's superiors assume must be referring to questionable forms of animal husbandry (Murakami 1990b, 232). The control exerted by the sheep, and the ruined lives it leaves in its wake in Hokkaido and Korea particularlyform a subtle correlation with the military occupation, industrial expansion and rape associated with Japanese colonialism. In this way, Murakami traces patterns of political, military and business collusion in Japan's modern imperial project from its inception.

Once Boku appears to have reached a dead end in the mystery, shut away in Rat's abandoned Hokkaido lodge with only a mysterious local crank in a sheepskin suit for company, he discovers that Rat has already committed suicide, trapping the sheep in his dead body. Reappearing as a ghost, Rat explains to Boku that he was selected as the successor to the sheep's empire, but refused. Rat's ghost has one last request of Boku: that he complete the destruction of the sheep by setting a time bomb in the lodge, killing the Strange Man and putting a stop to the cycle of violence once and for all.

The friends' final ghostly conversation brings closure to the two major recurring images associated with Rat, having made their first appearances in Hear the Wind Sing and Pinball, 1973: weakness and decay, respectively. Given a chance to speak his piece, the ghost of Rat explains that he has always felt “a weakness pulling [him] into darkness” (暗闇に引きずり込まれていく弱さ) (Murakami 1990b, 355). He describes this weakness as "something that rots in the body" (体の中で腐っていくもの)—a similar turn of phrase to his final conversation with bartender J at the close of Pinball, 1973 (1990b, 355-56). ${ }^{22}$ This weakness leaves him vulnerable to the influence of the sheep, but also offers the only possible resistance to it. Rat explains:

I guess I felt attached to my weakness. My pain and suffering too. Summer light, the smell of a breeze, the sound of cicadas-if I like these things, why should I apologize? ${ }^{23}$

(Murakami 2003, 306)

In an allusion to the first book of the series, Rat explicitly associates the weakness that gives him the ability to resist the sheep, who has become associated with corruption and conformity to power, with the same love for living things that first inspired his decision to begin writing in Hear the Wind Sing-cicadas and the summer breeze. Embracing this shutaisei allows him to resist becoming co-opted by the forces of the militaristic Right, though it comes at the cost of his own life. The ghostly encounter gives Boku the chance to reconnect with Rat one last time and inspires in him a long-forgotten sense of shutaisei, prompting Boku to fulfill his friend's final request to stop the sheep for good.

Rat's sacrifice, and Boku's decision to follow through on his old friend's request to destroy the lodge and the Strange Man, is able to disrupt the 
sheep's cycle of reincarnation and colonial violence. This restores Boku's emotional engagement with the outside world, and he returns to J's Bar to talk about the events of his strange journey (presumably over a whiskey). The series ends with a scene of profound emotional catharsis:

I walked along the river to its mouth. I sat down on the last fifty yards of beach, and I cried. I never cried so much in my life. I brushed the sand from my trousers and got up, as if I had somewhere to go. The day had all but ended. I could hear the sound of waves as I started to walk. ${ }^{24}$

(Murakami 2003, 306)

Murakami's conclusion to the Rat Trilogy thus implies that, comforting though they may be to have around, the spirit of the late 1960s cannot be revived through imported jazz records, the Beach Boys or pinball. Rather, this is only achieved through the harsh business of self-reflection, self-destruction and ultimately self-renewal. These are the processes that form shutaisei, and pave the way for meaningful resistance. This is what Rat, standing in for the values of the student movement, is finally able to communicate to the previously cold, clinical and materialistic Boku.

It is in this way that Boku's journey to Hokkaido makes explicit the student movement's notion of challenging the everydayness described by Ando $(2013,1)$. Like the unaligned masses whose consciousness the students aimed to transform, Boku is shaken out of his relatively comfortable and affluent existence due to his contact with Rat, the former activist who still maintains his counter-cultural lifestyle even as Boku drifts away from its ideology of resistance. For the first two books, Boku is ostensibly content to acquiesce to the everyday and consider the 1960 s only in terms of its pop culture, free of political commitment. Rat, on the other hand, can only maintain his values and political shutaisei at the expense of personal relationships, as the everydayness he seeks to question has proven itself quite agreeable to Boku. However, through each of his interactions with the sheep's former hosts, Boku becomes more keenly aware of the complex impact of Japan's colonial aggression and his own affluent life, until he can no longer accept that this is 'just the way things are'. Murakami makes visible the invisible networks of power and control through the looming presence of the sheep, an apparently absurd and nonthreatening entity that nevertheless must be resisted and defeated once made tangible.

Against the sheep - the hidden incarnation of right-wing militarism, now identified as the object of political resistance by the dejected former activist Rat and the withdrawn loner Boku - the estranged friends are able to team up and disrupt the unspoken networks of power that have hitherto perpetuated its control. Exploring and confronting the complex forces underlying the mundane grants each friend an outlet to express his shutaisei, even though the mass demonstrations of their university days are long behind them. In the allegory that connects these three novels, Murakami shows that through 
the long, hard work of self-reflection and self-negation, the previously apathetic Boku and the embittered Rat are able to reassert their moral, social and political sense of self and being in the world: in other words, their commitment.

To assert the presence of commitment in the Rat Trilogy naturally questions the usual arc attributed to Murakami's work. Should his work continue to progress along the popularly asserted detachment-to-commitment trajectory, Murakami's future work should reflect on recent changes in the national zeitgeist. Indeed, such a process may already have begun. Norihiro Katō has recently observed in an interview with The Asahi Shimbun's Hiroshi Matsubara (2014) that the final chapter of Murakami's 2013 novel Colorless Tsukuru Tazaki and His Years of Pilgrimage marks the author's first direct response to the 11 March 2011 catastrophe, with the protagonist's quest to reconnect with lost friends appearing to serve as a plea for a more cooperative and supportive society. This dovetails with Murakami's own words upon receiving the International Catalunya Prize in June 2011, when he said in the context of Japan's response to the triple disaster that

[i]n this great collective effort, there should be a space where those of us who specialize in words, professional writers, can be positively involved. We should weave together with words new morals and new ethical standards. We should plant vibrant new stories and make them sprout and flourish. Those stories will become our shared story.

(Murakami 2011)

It might then be argued that Murakami's sense of commitment may have led him to make such claims more explicitly in recent years. Nevertheless, if (as both Murakami and his commentators seem to agree) Colourless Tsukuru Tazaki and His Years of Pilgrimage uses individual conflicts as allegories for broader social issues, it is important to consider when and where this tendency originated in Murakami's work. When understood through the student movement, the Rat Trilogy illustrates that Murakami has grappled with defining what constitutes social commitment, its personal cost, as well as its communal legacy, since his earliest works.

\section{CONCLUSION}

At the core of the 1960s student movement, there existed a tension between affirming the moral agency of the individual and pressing the need for individuals to enact change on society through direct action. Murakami wrestles with this same dilemma of moral subjectivity versus large-scale social engagement in the Rat Trilogy, through Boku and Rat's reactions to the end of 1960s student activism. The series proffers a scenario in which both men seem to have failed in their own ways to express the kind of subjectivity that activists had put at the forefront of the late 1960s movement, and traces their attempts to fill this emotional void in the absence of a unifying political purpose. 
Allegorically, the arc of the Rat Trilogy shows how Boku and Rat are ultimately able to regain the ability to resist everydayness and exercise their subjectivity by defeating the vast far-right conspiracy represented by the sheep. Although bittersweet, the trilogy ends on a note of hope, with Boku finding emotional catharsis and the promise that even without large-scale demonstrations to give some rhythm and structure to dissent, there are meaningful ways for individuals to resist becoming co-opted by threatening power structures. Rather than following Murakami's often touted yet overly simplistic trajectory of detachment to commitment, the allegorical politics of individual subjectivity in the Rat Trilogy suggest that a complex balancing act between these two impulses has always existed in Murakami's writing, even despite the writer's own claims to the contrary.

\section{APPENDIX: LIST OF REFERENCED HARUKI MURAKAMI WORKS,} 1979-2013

\begin{tabular}{|c|c|c|c|}
\hline Title [English] & Title [Japanese] & Title [Romanisation] & $\begin{array}{l}\text { Year of } \\
\text { Publication } \\
\text { /Release }\end{array}$ \\
\hline Hear the Wind Sing & 風の歌を聴け & Kaze no uta o kike & 1979 \\
\hline Pinball, 1973 & 1973 年のピンボール & 1973 nen no pinbōru & 1980 \\
\hline A Wild Sheep Chase & 羊をめぐる冒険 & Hitsuji o meguru bōken & 1982 \\
\hline $\begin{array}{l}\text { Hard-Boiled } \\
\text { Wonderland and the } \\
\text { End of the World }\end{array}$ & $\begin{array}{l}\text { 世界の終りとハード } \\
\text { ボイルド・ワンダー } \\
\text { ランド }\end{array}$ & $\begin{array}{l}\text { Sekai no owari to hādo } \\
\text { boirudo wandārando }\end{array}$ & 1985 \\
\hline Dance Dance Dance & ダンス・ダンス・ダンス & Dansu dansu dansu & 1988 \\
\hline $\begin{array}{l}\text { The Wind-Up Bird } \\
\text { Chronicle }\end{array}$ & ねじまき鳥クロニクル & $\begin{array}{l}\text { Nejimakidori } \\
\text { kuronikuru }\end{array}$ & 1995 \\
\hline Underground & アンダーグラウンド & Andāguraundo & 1997 \\
\hline $\begin{array}{l}\text { Colorless Tsukuru } \\
\text { Tazaki and His Years } \\
\text { of Pilgrimage }\end{array}$ & $\begin{array}{l}\text { 色彩を持たない多崎 } \\
\text { つると、彼の巡礼 } \\
\text { の年 }\end{array}$ & $\begin{array}{l}\text { Shikisai o motanai } \\
\text { Tazaki Tsukuru to, kare } \\
\text { no junrei no toshi }\end{array}$ & 2013 \\
\hline
\end{tabular}

\section{GLOSSARY}

\section{Anpo (安保)}

Japanese abbreviation for Nihonkoku to Amerika gasshūkoku tono aida no sōgo kyōryoku oyobi anzen hoshō jōyaku (日本国とアメリカ合衆国との間の相互協力及び安全 保障条約; Treaty of Mutual Cooperation and Security between the United States and Japan), first instituted in 1952 following the Treaty of San Francisco

\section{boku (僕)}

informal first-person masculine pronoun; also, used to refer to the unnamed protagonist Boku in the Rat Trilogy

\section{hakai katsudō bōshi hō (破壊活動防止法)}

Antisubversive Activities Law

junbungaku (純文学)

lit., 'pure literature' or high literature; literature acknowledged as having the aesthetic qualities and social importance expected of high art 
moratoriamu ningen (モラトリアム人間)

lit., 'moratorium people'; youth who came of age after the late 1960s student movements, characterised as having chosen not to commit to ideologies or agitate for reform in social institutions, in order to be free to enjoy Japan's burgeoning consumer culture

nichijōsei (日常性)

a term defined by New Left activists as the complex system of social control and oppression supporting comfortable 'everyday' life in Japan's postwar economic boom

ore (俺)

very informal first-person masculine pronoun

otaku (オタク)

a person with an obsessive interest, typically in some form of popular culture or consumer commodity

\section{shutaisei (主体性)}

roughly 'individual agency' or 'subjectivity', it is a complex term referring to individual autonomy, both in the political sense as well as that of moral integrity; its meaning was ferociously debated within the postwar Japanese Left

\section{taishū bungaku (大衆文学)}

lit., 'mass literature' or popular literature; typically referring to literature, especially genre fiction, aimed at a commercial audience

\section{Zengakuren (全学連)}

All-Japan Student Union; a New Left-leaning student government organisation that broke ties with the Japanese Communist Party and instigated the major campus protests of the late 1960s

\section{REFERENCES}

Ando, T. 2013. Japan's New Left Movements: Legacies for Civil Society. London and New York: Routledge.

Beale, L. 1991. "The Cool, Cynical Voice of Young Japan," Los Angeles Times, 8 December. Accessed 10 October, 2016. http://articles.latimes.com/1991-1208/magazine/tm-233_1_haruki-murakami.

Bible Study Tools. 2017. "Matthew 5." Accessed 2 June, 2017. http://www. biblestudytools.com/kjv/matthew/5.html.

Dil, J. 2010. "Writing as Self-therapy: Competing Therapeutic Paradigms in Murakami Haruki's Rat Trilogy.” Japan Forum 22 (1-2): 43-64. http://doi. org/10.1080/09555803.2010.488942.

Eckersall, P. 2013. Performativity and Event in 1960s Japan: City, Body, Memory. New York: Palgrave Macmillan. 
Erickson, S. 2015. "Haruki Murakami's 'Wind/Pinball'," New York Times, 12 August. Accessed 10 November, 2016. http://www.nytimes.com/2015/08/16/books/ review/haruki-murakami-wind-pinball-review.html.

Karatani, K. [柄谷＼cjkstart行人]. 1990. Shūen o megutte [終焉をめぐって]. Tokyo: Fukutake Shoten [福武書店].

Kawai, H. [河合 隼雄] and H. Murakami [村上 春樹]. 1996. Murakami Haruki to Kawai Hayao ni ai ni iku [村上春樹と川井隼雄に会いに行く]. Tokyo: Iwanami Shoten [岩波書店].

Kelman, P. 2001. "Protesting the National Identity: The Cultures of Protest in 1960s Japan.” PhD dissertation, University of Sydney.

Kersten, R. 2009. "The Intellectual Culture of Postwar Japan and the 1968-1969 University of Tokyo Struggles: Repositioning the Self in Postwar Thought." Social Science Japan Journal 12 (2): 227-45.

Kimura, M. [木村 政樹]. 2014. “'Akuchuariti” no jidai: junbungaku-ron ni okeru Hirano Ken” [「アクチュアリティ」の時代:純文学論争における平野謙]. Nihon kindai bungaku [日本近代文学] 90: 93-108.

Kinsella, S. 1998. "Japanese Subculture in the 1990s: Otaku and the Amateur Manga Movement.” The Journal of Japanese Studies 24 (2): 289-316.

Koschmann, J. V. 1996. Revolution and Subjectivity in Postwar Japan. Chicago: University of Chicago Press.

Kuroko, K. [黒古 一夫]. 2007. Murakami Haruki sōshitsu no monogatari kara tenkan no monogatarie [村上春樹「喪失」の物語から「転換」の物語へ]. Tokyo: Bensei Shuppan [勉誠出版]

2015. Murakami Haruki hihan [村上春樹批判]. Tokyo: Arts and Crafts [アーツアンドクラブツ].

Kuronuma, K. [黒沼克史]. 1999. “Detachimento kara komittomento e” [デタッチメ ントからコミットメントー]. In Murakami Haruki sutadizu 04 [村上春樹スタデデ イーズ 04], edited by Y. Kuritsubo [栗坪 良樹] and T. Tsuge [柘植 光彦], 236-41. Tokyo: Wakakusa Shobō [若草書房].

Matsubara, H. 2014. "'Colorless Tsukuru Tazaki' is an Imperfect Work but One of Haruki Murakami's Most Important," The Asahi Shimbun, 16 March. Accessed 25 October, 2016. http://archive.is/BwwqQ.

Miyoshi, M. 1994. Off-Center: Power and Culture Relations between Japan and the United States. Cambridge: Harvard University Press.

Murakami, H. [村上＼cjkstart春樹]. 1985 [1980]. Pinball, 1973. Translated by A. Birnbaum. Tokyo: Kodansha English Library.

1987 [1979]. Hear the Wind Sing. Translated by A. Birnbaum. Tokyo: Kodansha English Library. 
2003 [1982]. A Wild Sheep Chase. Translated by A. Birnbaum. London: Vintage.

. 1990a. Murakami Haruki zensakuhin 1979-1989 (1) [村上春樹全作品 1979$1989\langle 1>$ ]. Tokyo: Kōdansha [講談社].

1990b. Murakami Haruki zensakuhin 1979-1989 (2) [村上春樹全作品 1979$1989\langle 2>$ ]. Tokyo: Kōdansha [講談社].

. 2011. "Speaking as an Unrealistic Dreamer." Translated by E. Pastreich. The Asia-Pacific Journal 9 (29). http://apjjf.org/2011/9/29/MurakamiHaruki/3571/article.html.

Murakami, H. [村上 春樹] and J Wray. 2004. "Haruki Murakami, The Art of Fiction No. 182." The Paris Review 170. Accessed 8 February, 2017. http:// www.theparisreview.org/interviews/2/haruki-murakami-the-art-of-fictionno-182-haruki-murakami.

Ōe, K. 1994. "Japan, The Ambiguous, and Myself." Speech. Nobel Media. Accessed 21 October, 2016. http://www.nobelprize.org/nobel_prizes/literature/ laureates/1994/oe-lecture.html.

Oguma, E. [小熊 英二]. 2009. 1968 jō: wakamonotachi no hanran to sono haikei [1968〈上〉若者たちの叛乱とその背景]. Tokyo: Shin’yōsha [新曜社].

. 2015. “Japan's 1968: A Collective Reaction to Rapid Economic Growth in an Age of Turmoil." Translated by N. Kapur with S. Malissa and S. Poland. The Asia-Pacific Journal 13 (12). Accessed 25 October, 2016. www.japanfocus. org/-Oguma-Eiji/4300/article.html.

Okonogi, K. [小此木 啓吾]. 1978. “The Age of the Moratorium People.” Japan Echo $5(1), 17-39$.

Rubin, J. 2002. Haruki Murakami and the Music of Words. London: Random House.

Sasaki, F. 2012. Nationalism, Political Realism and Democracy in Japan: The Thought of Masao Murayama. London and New York: Routledge.

Seats, M. 2006. Murakami Haruki: The Simulacrum in Contemporary Japanese Culture. Lanham: Lexington Books.

Steinhoff, P. 1984. "Student Conflict." In Conflict in Japan, edited by E. Krauss and T. Rohlan, 174-213. Honolulu: University of Hawai'i Press.

Takayama, K. 2007. Right Turn in Japan's Third Great Education Reform: A Critical, Globalization Approach to the Studies of Japanese Education. Ann Arbor: University of Michigan Press.

Takeda, S. [武田 政治]. 1995. Ririshizumu no jōken o tou koto [リリシズムの条件を 問うこと]. Kokubungaku [国文学] 40 (4): 32-35.

Tanaka Atkins, M. 2012. "Time and Space Reconsidered: The Literary Landscape of Murakami Haruki.” PhD dissertation, University of London. 
Watatsuki, T. 2016. “The Haruki Phenomenon and Everyday Cosmopolitanism." In Haruki Murakami: Challenging Authors, edited by M. Strecher and P. Thomas, 1-16. Rotterdam: Sense Publishing.

Yasko, G. 1997. "The Japanese Student Movement 1968-1970: The Zenkyōtō Uprising." PhD dissertation, Cornell University.

Yoshida, H. [吉田＼cjkstart春生]. 1997. Murakami Haruki, tenkan suru [村上春樹、転換する]. Tokyo: Sairyūsha [彩流社]. 